\title{
The foundation and development of Na Fianna Éireann, 1909-16
}

$\mathrm{T}$

This article examines the establishment and development of Na Fianna Éireann, or the Irish National Boy Scouts, in the period 1909-16. It also assesses the contributions of the organisation's two founders, Countess Constance Markievicz and Bulmer Hobson, in the early years of its existence. Bureau of Military History witness statements, a key source for the history of the Fianna, indicate that a degree of controversy surrounds the relative importance of the pair in the foundation and control of the Fianna movement.

During the first seven years of its existence, this nationalist youth organisation developed branches in at least nineteen Irish counties - mainly in the cities and larger towns of Leinster, Munster and Ulster - as well as in Glasgow and Liverpool. ${ }^{1}$ Many members of the Fianna participated in the Easter Rising, some serving as commanders and fighters, others engaged in carrying dispatches, scouting and reconnoitring. The organisation later played an active role in the Irish War of Independence and Civil War. Yet despite the Fianna's involvement in the Irish independence movement, it has not been the subject of a specialist study. ${ }^{2}$

Na Fianna Éireann was one of many 'pseudo-military youth groups' that proliferated in Europe in the late nineteenth and early twentieth centuries. These organisations were not only a manifestation of the cult of discipline, training and manliness that grew out of the menace of the coming war, ${ }^{3}$ but also, perhaps, a reaction to the widely perceived fin-de-siècle 'decadence'. The most famous of these youth groups is Robert Baden-Powell's Boy Scouts' movement.

Baden-Powell, a British army officer who specialised in reconnaissance and scouting, had established the Boy Scouts' movement in 1908 in response to the interest that boys had shown in his 1899 army training manual, Aids to scouting. He was also inspired by the model of the Boys' Brigade. This latter organisation was founded by William Alexander Smith in 1883 in Glasgow. Smith used the novelty of military drill and discipline as a way of encouraging teenage workingclass boys to continue attending his Scottish Free Church Sunday School. ${ }^{4}$

1 This data is derived from the reports provided by the Fianna that were regularly published in the newspapers Irish Freedom (1910-14) and Irish Volunteer (1914-16). These reports may not have mentioned all of the branches in existence. For instance, the only Connacht-based Fianna troop noted in these reports was in Tuam.

2 J. A. Gaughan included a section on the Fianna in his general account of the boy-scouts' movement in Ireland, but did not include full citations of sources (Scouting in Ireland (Dublin, 2006)).

3 David Fitzpatrick, 'Militarism in Ireland, 1900-1922' in Thomas Bartlett and Keith Jeffery (eds), A military history of Ireland (Cambridge, 1996), pp 382-3.

4 Paul Wilkinson, 'English youth movements, 1908-30' in Journal of Contemporary History, iv (1969), p. 5. 
Baden-Powell put less overt emphasis on militarism. Instead, he focused on outdoor activities and personal development in order to counter what he saw as the moral and physical decline of the upcoming generation. He also wanted to train boys to be better citizens. ${ }^{5}$ Whether his main concern before 1920 was training citizens or future soldiers has sparked much scholarly debate. ${ }^{6}$ In any case, the Baden-Powell Boy Scouts emphasised the importance of such traits as discipline, trust, obedience, loyalty, manliness, service and self-sacrifice. ${ }^{7}$

Na Fianna Éireann promoted these same qualities, but in an Irish nationalist rather than British imperialist context. The Irish organisation offered its members a combination of military training, outdoor activities and cultural endeavours. In the light of Ireland's history of religious division, it is not surprising that the Fianna eschewed the Bible study of the Boys' Brigade and the non-denominational, nature-loving Christian spirituality of the Baden-Powell movement. ${ }^{8}$ Open to individuals of all creeds, the Fianna emphasised the importance of morality, but rarely made reference to religion.

Markievicz and Hobson, two Irish Protestant nationalist activists, launched $\mathrm{Na}$ Fianna Éireann in August 1909 in order to counteract the influence in Ireland of the pro-British Boy Scouts' movement. A recent convert to nationalism, Markievicz was in her early forties and came from a landed Anglo-Irish background. Hobson, her early patron within the Irish nationalist movement, was the product of a progressive Belfast Quaker family. Though only twenty-six years of age, he was already a prominent Sinn Féin propagandist and rising member of the Irish Republican Brotherhood (I.R.B.).

Their new organisation for boys was the militarised reincarnation of a boys' hurling club, also called Na Fianna Éireann, that Hobson had founded in Belfast in 1902. The excitement surrounding the inaugural meeting of that first incarnation of the Fianna had convinced Hobson that the fledgling organisation was something that could be moulded 'into a strong force to help in the liberation of Ireland'. But due to lack of money and the pressures of Hobson's various political and cultural commitments, the Belfast organisation had lapsed before it could live up to this dream. Seven years later, in Dublin, he had a second chance to explore the potential for his brainchild to become a strong force to aid in the struggle for Irish freedom. This was due to the impetus provided by Markievicz.

Having read a newspaper account of the lord lieutenant, Lord Aberdeen's, interest in a number of Boys' Brigades and Boy Scouts' troops, the countess had decided to

5 Henry Collis, Fred Hurll and Rex Hazlewood, B.-P.'s Scouts: an official history of the Boy Scouts Association (London, 1961), pp 48, 55.

6 See Michael Rosenthal, 'Knights and retainers: the earliest version of Baden-Powell's Boy Scout scheme' in Jn. Contemp. Hist., xv (1980), pp 603-17; Allen Warren, 'Sir Robert Baden-Powell, the Scout movement and citizen training in Great Britain, 1900-1920' in E.H.R., ci (1986), pp 376-98; John Springhall, 'Baden-Powell and the Scout movement before 1920: citizen training or soldiers of the future?' in E.H.R., cii (1987), pp 934-42; Anne Summers, 'Scouts, Guides and VADs: a note in reply to Allen Warren' in ibid., pp 943-7; Allen Warren, 'Baden-Powell: a final comment' in ibid., pp 948-50.

7 R. S. S. Baden-Powell, Scouting for boys: handbook for instruction in good citizenship (London, 1908), p. 266.

8 For a discussion of the spiritual aspects of the Boy Scouts' movement, see Warren, 'Baden-Powell, Scout movement and citizen training', pp 388-91.

9 Bulmer Hobson, Ireland yesterday and tomorrow (Tralee, 1968), p. 15. 
administer a nationalist antidote. ${ }^{10}$ She initially approached Arthur Griffith about gaining support from Sinn Féin for the establishment of a nationalist boy-scout troop, but was turned down - no doubt due to her vision of a physical-force troop and her existing connection with Hobson, who was Griffith's rival for leadership within the Sinn Féin movement. ${ }^{11}$ Ironically, Griffith had been in favour of the formation of a nationalist Boys' Brigade-style organisation when Hobson, who was not yet a threat, had established the first incarnation of the Fianna in 1902. ${ }^{12}$

In order to attract boy recruits, Markievicz decided to contact a schoolmaster with nationalist sympathies. She was directed to William O'Neill, who taught at St Andrew's National School on Brunswick Street. ${ }^{13}$ During a visit to I.R.B. leader Tom Clarke's shop, the countess mentioned that she was planning to approach O'Neill about recruiting some boys to start a nationalist boy-scout troop. Clarke 'thought it a good idea but pointed out to her that as she was a non-Catholic O'Neill might look upon her with suspicion. In fact ... he might suspect proselytism.' At Clarke's suggestion, she asked Seán McGarry, a future president of the I.R.B. Supreme Council, to accompany her. They evidently passed muster, as O'Neill introduced them to eight or nine boys, who helped form the nucleus of what would later become the Fianna. ${ }^{14}$

The countess invited these boys to her home in Rathgar, and dubbed them the Red Branch Knights. With the help of nationalist activist Helena Molony, McGarry and another I.R.B. member, Patrick McCartan, she tried - unsuccessfully - to instruct them in signalling, drill and scouting, while they - successfully - raided her husband's whiskey supply. ${ }^{15}$ After a chaotic camping trip with the boys, the countess decided that the only way for the experiment to work was to organise the project on a more official footing.

Upon hearing about Hobson's Belfast Fianna, Markievicz declared that a national boys' organisation should be established in Dublin in the same spirit as the original group. Hobson pointed out that the biggest obstacle to starting such an organisation was funding. Money, however, was no object to Markievicz, ${ }^{16}$ and in August 1909 she secured Hobson's assistance and rented a hall at 34 Lower Camden Street in Dublin. At his request, the Red Branch Knights became Na Fianna Éireann as a memorial to his youthful Belfast adherents. ${ }^{17}$

To make his dream come true of creating 'a strong force to help in the liberation of Ireland', ${ }^{18}$ Hobson needed Markievicz's energy, enthusiasm, initial injection of money and, due to her gender and social position, ability to inspire the trust and

\footnotetext{
${ }^{10}$ Anne Marreco, The rebel countess (London, 1967), p. 112; Jacqueline Van Voris, Constance de Markievicz in the cause of Ireland (Amherst, Mass., 1967), p. 67.

${ }_{11}$ Marreco, Rebel countess, pp 113-14.

${ }_{12}$ United Irishman, 24 Jan. 1903.

${ }_{13}$ Marreco, Rebel countess, p. 114.

${ }^{14}$ Sean McGarry, Bureau of Military History (henceforth B.M.H.) witness statement, 15 Apr. 1950 (N.A.I., B.M.H., WS 368).

${ }^{15}$ Marreco, Rebel countess, p. 115.

${ }^{16}$ Bulmer Hobson, 'The I.R.B. and the Fianna' in F. X. Martin (ed.), The Irish Volunteers 1913-1915: recollections and documents (Dublin, 1963), pp 18-19; Sean O'Faolain, Constance Markievicz, (2nd ed., London, 1987), p. 85; Van Voris, Constance de Markievicz, pp 69-70.

${ }_{17}$ Marreco, Rebel countess, p. 117.

${ }^{18}$ Hobson, Ireland, p. 15.
} 
confidence of the parents of the younger boys. ${ }^{19}$ Without her, he probably would not have attempted to resurrect the Fianna. To make her dream come true, she needed his organisational experience, the template of his previous boys' group, and (though she may not have been aware of it) his I.R.B. connection.

On Monday 16 August 1909, in the Camden Street hall, Hobson chaired a meeting 'to form a National Boys' Organisation to be managed by the boys themselves on national non-party lines'. ${ }^{20}$ Estimates suggest that between thirty and 100 boys, 'mostly adventurers from the Coombe and neighbourhood', turned up for this meeting to form what became known as Na Fianna Éireann. ${ }^{21}$ Markievicz and a few other adults were also in attendance. In his address, Hobson explained that the organisation would be run on a semi-military basis along the lines of the Boy Scouts' movement founded in the previous year by Baden-Powell. In fact, it was one of the immediate objectives of this new group to counteract the influence in Ireland of Baden-Powell's pro-British body. ${ }^{22}$

Michael Lonergan was about fifteen years of age when he attended the inaugural meeting of the Fianna. He later viewed this meeting held in a 'dingy' theatrical hall as the beginning - militarily - of the events leading up to Easter Week. ${ }^{23}$ The Fianna was the first nationalist group in Ireland to begin drilling; it went on to train members of the I.R.B., and its members were among the few men, other than ex-British soldiers, to possess the military training necessary to become officers when the Irish Volunteers was formed in 1913.

When Markievicz told Clarke about her plans to start a nationalist boys' group, and solicited the assistance of McGarry, McCartan and Hobson, she approached them not as I.R.B. members but rather as fellow nationalists. This supports Hobson's claim that the I.R.B. was not formally consulted and did not play an official part in the establishment of the Fianna. Despite this, Hobson's own aim was 'to recruit suitable members of the new Fianna into the I.R.B.' ${ }^{24}$

Patrick Ward, who attended the inaugural meeting of the Fianna with his friend Eamon Martin, reported that Markievicz, Hobson and Pádraig Ó Riain acted as the initial organising committee. He recalled:

Madame Markievicz was very intense. She was the first person who captured your notice; then Bulmer Hobson, very quiet and affable and very competent to deal with any question you would like to put, was next, apparently, in our mind in importance ... There was also Pádraig Ó Riain, a good, efficient secretary.

Soon afterwards, Ward came to reverse his assessment of the relative importance of these three individuals, instead considering Ó Riain 'as by far the most significant member of that small committee at the time'. Ward regarded Ó Riain's

${ }^{19}$ Helena Molony, B.M.H. witness statement, n.d. [prob. 1950] (N.A.I., B.M.H., WS 391).

${ }^{20}$ Hobson, 'I.R.B. and Fianna', pp 18-19.

${ }^{21}$ Michael Lonergan, B.M.H. witness statement, 1 Aug. 1948 (N.A.I., B.M.H., WS 140); Seamus Mac Caisin, B.M.H. witness statement, 8 June 1947 (ibid., B.M.H., WS 8).

${ }^{22}$ Eamon Martin, B.M.H. witness statement, n.d. (ibid., B.M.H., WS 591).

${ }^{23}$ Michael Lonergan, B.M.H. witness statement, 1 Aug. 1948 (ibid., B.M.H., WS 140).

${ }^{24}$ Hobson, 'I.R.B. and Fianna', p. 20. 
'intellectual and studious development' as ten years in advance of his age, adding that he possessed 'a quiet sense of humour and perfect sense of justice'. ${ }^{25}$

Eamon Martin and Hobson agreed with this assessment of Ó Riain, a young Gaelic Leaguer. ${ }^{26}$ Martin recalled that though Ó Riain appeared to be about sixteen or seventeen, 'it was quite obvious that he was well used to meetings and their procedure', and that he had a 'capacity for orderly organisation' ${ }^{27}$ Hobson also praised Ó Riain, citing him as the 'dominating personality in the Fianna' during the period 1909-16. Hard-working and a natural leader, Ó Riain was responsible, in his view, for the success of the Fianna in these critical years. ${ }^{28}$

Accounts of this first Fianna meeting provide differing details regarding the election of an executive council. All accounts agree that Hobson was elected president. Some refer to the election of Markievicz and Ó Riain as joint secretaries, while others suggest that Markievicz became vice-president and Ó Riain secretary. This discrepancy may have arisen because a number of organisational meetings were held at the time. ${ }^{29}$

The election of the countess was controversial. Many boys were reluctant to accept a woman in office because they felt that there was no place for a female in a physical-force association. ${ }^{30}$ Ironically, she was the best-qualified person in the hall to teach them how to handle firearms. ${ }^{31}$ According to Hobson, he often had to point out discreetly that the boys could not take her money and at the same time deny her membership or office. However, 'this feeling against the presence of a woman in the organisation continued in varying degrees of intensity for many years and probably never completely disappeared'. ${ }^{32}$

While Markievicz provided an initial injection of money to start the organisation, in actual fact Na Fianna Éireann's ongoing funding came from the boys' own subscriptions of a penny a week and from events such as concerts. In addition, Roger Casement provided gifts of money, and Hobson engaged in various fundraising activities. ${ }^{33}$ Between July 1911 and June 1912, Hobson's efforts brought in $£ 10$, almost one third of the Fianna's annual income for that year. ${ }^{34}$

Na Fianna Éireann soon developed a formal organisational structure. In addition to its executive, ${ }^{35}$ the Fianna consisted of an ard-fheis (congress), an ard-choisde (central council), district councils and sluaighte (troops). The ard-fheis, which met annually, was the 'supreme governing and legislative body of the Fianna'. It

${ }_{25}$ Patrick Ward, B.M.H. witness statement, 30 Mar. 1955 (N.A.I., B.M.H., WS 1, 140).

${ }^{26}$ Cathleen McCarthy (née Ryan), B.M.H. witness statement, 31 Mar. 1954 (ibid., B.M.H., WS 937); Seamus Mac Caisin, B.M.H. witness statement, 8 June 1947 (ibid., B.M.H., WS 8).

${ }^{27}$ Eamon Martin, B.M.H. witness statement, n.d. (ibid., B.M.H., WS 591).

${ }^{28}$ Hobson, 'I.R.B. and Fianna', p. 23.

${ }^{29}$ Eamon Martin, B.M.H. witness statement, n.d. (N.A.I., B.M.H., WS 591); Patrick Ward, B.M.H. witness statement, 30 Mar. 1955 (ibid., B.M.H., WS 1, 140); Hobson, Ireland, p. 16; Marreco, Rebel countess, p. 117; Van Voris, Constance de Markievicz, p. 78.

${ }^{30}$ Seamus Mac Caisin, B.M.H. witness statement, 8 June 1947 (N.A.I., B.M.H., WS 8);

Marreco, Rebel countess, p. 117; Van Voris, Constance de Markievicz, p. 70.

${ }_{31}$ Marreco, Rebel countess, p. 118.

${ }^{32}$ Hobson, 'I.R.B. and Fianna', pp 18-19.

${ }^{33}$ Ibid., p. 21.

${ }^{34}$ Irish Freedom, Aug. 1912.

35 The executive included a president, two vice-presidents, an honorary secretary, an honorary assistant secretary and an honorary treasurer. 
consisted of the ard-choisde and delegates from the various sluaighte and district councils, which were formed in 1911 in Dublin and Belfast, where there were three or more sluaighte. The ard-choisde was responsible for the general direction of Na Fianna Éireann and served as the governing body of the organisation when the ard-fheis was not sitting. ${ }^{36}$

Shortly after the Fianna's formation, unemployment forced Hobson to move back to Belfast for a year. In his absence, the countess was elected president, a position she retained even after Hobson returned to Dublin in 1911 and resumed his active involvement with the Fianna. ${ }^{37} \mathrm{He}$ sat on the ard-choisde until the 1916 Rising, and served as vice-president until the Fianna's reorganisation in mid-1915. ${ }^{38}$ In this capacity, he often chaired the quarterly meetings of the Dublinbased ard-choisde, and represented it at regional conferences, such as that of the Munster sluaighte held in Limerick in 1915. ${ }^{39}$

An Cead Sluagh, the first Fianna troop, was born out of the inaugural meeting in August 1909. Its members met regularly in the Camden Street hall, adopting a jersey and kilt as their uniform. ${ }^{40}$ Other Fianna members chose to wear breeches and a tunic with brass buttons. Con Colbert, later executed for his role in the 1916 Rising, was the first instructor in elementary drill formations. Eamon Martin reported: '[Colbert] was no great expert at this time. By intense swotting, however, he improved as the weeks went on, and, consequently, so did the sluagh.' Later on, certain members of the sluagh, such as the dapper Michael Lonergan, emerged as natural instructors. Through involvement with the Fianna, the boys participated in elementary drill and route marching, and learned signalling, first aid, and other scouting skills such as map reading, path-finding and elementary astronomy. They also learned the Irish language and Irish history, particularly the history of battles and insurrections. As Martin explained, 'in this way the boys were being given a reason for their own military training., ${ }^{41}$

The Fianna initially faced 'opposition, ridicule and indifference', even from fellow nationalists. ${ }^{42}$ For instance, a correspondent to Griffith's Sinn Féin newspaper was keen to dissociate the local branches of Sinn Féin and the Gaelic League from the new boys' group. ${ }^{43}$ Publications associated with Hobson, such as the I.R.B. newspaper Irish Freedom and the Irish Volunteer organ, were more supportive, and published regular reports of Fianna activities. ${ }^{44}$ In December 1910 Irish Freedom noted:

The interest taken in the Fianna by young and old is gradually, if slowly, increasing as they increase in numbers. There are those who think the organisation of little importance because it is made up of boys, but such people forget that though one may be too young to be the possessor of that powerful weapon called a vote, nobody is too young to serve his country, and, if necessary, fight for his country.

${ }^{36}$ The constitution of Na Fianna Éireann as amended by the ard-fheis, 1912 (Dublin, 1912), p. 2; Fianna handbook (Dublin, 1914), p. 15.

${ }^{37}$ Hobson, 'I.R.B. and Fianna', p. 21; Hobson, Ireland, p. 17.

${ }^{38}$ Irish Freedom, Aug. 1913.

${ }^{39}$ Ibid., Jan. 1914; Irish Volunteer, 5 June 1915.

${ }^{40}$ Garry Holohan, B.M.H. witness statement, n.d. (N.A.I., B.M.H., WS 328).

${ }^{41}$ Eamon Martin, B.M.H. witness statement, n.d. (ibid., B.M.H., WS 591).

42 Irish Freedom, Sept. 1911.

${ }^{43}$ Sinn Féin, 21 Aug. 1909.

${ }^{44}$ Hobson was one of the editors of Irish Freedom until June 1914, and served as the business manager and unofficial editor of Irish Volunteer from December 1914 onwards. 
The young age at which Robert Emmet first attracted the notice of the British authorities was cited as a reminder of what boys could achieve. ${ }^{45}$

Between 1909 and 1913, the growth of the organisation was slow and often unsteady. By January 1911 there were over 150 members of the Fianna in Belfast alone. At the second annual ard-fheis, held in the summer of 1911, fifteen sluaighte were affiliated, including seven in Dublin and six in Belfast. ${ }^{46}$ However, many of these troops were 'in a very disorganised condition', and three soon collapsed. ${ }^{47}$ The situation improved over the ensuing year, and in July 1912 Ó Riain recorded the existence of 22 branches, 'all in a very healthy condition'. Between the summers of 1911 and 1912, three new troops had been established in County Dublin: one in the city and two others in Ballybrack and Lusk. ${ }^{48}$ Troops also existed in Derry, Athlone, Moate, Maryborough (Portlaoise), Enniscorthy and Rathkeale. ${ }^{49}$ The Limerick sluagh, which boasted 250 members, even opened the first purpose-built Fianna hall in the country, in December 1912. ${ }^{50}$

Growth of the organisation was often stunted, for a variety of reasons. Local members of the Ancient Order of Hibernians (A.O.H.) had broken up a sluagh in Newcastle West. In addition, the Belfast branches had faced 'serious difficulties' for reasons that were not elucidated. In July 1912 Ó Riain reported that 'one sluagh had to be suspended, and three others ceased to exist as sluaighte of the Fianna'. The Belfast district council, however, had established new troops to replace the ones lost. ${ }^{51}$ Nevertheless, a lack of funds limited the ard-choisde's ability to engage in systematic organisation around the country, and caused the postponement of publication of an instruction handbook. Aside from affiliation fees, which amounted to $£ 410$ s., most of its annual income for the year 1911-12 (£33 13s. 1d.) came from Dublin. It was believed that 'great work could be done' in County Wexford, where public opinion was favourable to the Fianna, if only the ard-choisde could afford to send an organiser there. Ultimately, publication of the Fianna handbook was delayed until 1914. ${ }^{52}$ Despite such setbacks, however, by 1913 the organisation had spread beyond the Dublin region to Belfast, Cork, Limerick, Derry, Waterford, Clonmel, Dundalk, Newry, Listowel and Glasgow. ${ }^{53}$

The Fianna purported to be a national, non-party organisation open to all Irish boys from the ages of eight to eighteen, no matter "what class or creed or party that

45 Irish Freedom, Dec. 1910.

${ }^{46}$ Bean na h-Éireann, Jan. 1911; Irish Freedom, Sept. 1911.

${ }^{47}$ Pádraig Ó Riain's (Hon. Gen. Sec.) report, 1912. A copy of this report can be found in a folder of Sinn Féin pamphlets in the N.L.I. (IR 94109 S13).

${ }^{48}$ Ibid.

${ }^{49}$ Irish Freedom, Dec. 1911 (edition edited by Dr Patrick McCartan); Irish Freedom, Sept. 1912; Ó Riain's report, 1912 (N.L.I., IR 94109 S13).

${ }^{50}$ Irish Freedom, Jan. 1913.

51 Ó Riain's report, 1912.

52 Ibid.

${ }^{53}$ Eamon Martin, B.M.H. witness statement, n.d. (N.A.I., B.M.H., WS 591); Van Voris, Constance, pp 72-3; Bean na h-Éireann, Jan. 1911; Irish Freedom, Sept. 1911. 
they or their fathers belong[ed] to' ${ }^{54}$ Over time, the organisation became openly militant, especially after selected senior members of the Fianna were recruited into the I.R.B. when they reached the age of seventeen. Ó Riain and Colbert joined the I.R.B. at an early stage. Eamon Martin and Patrick Ward became members in 1911, while Liam Mellows, Michael Lonergan and Garry Holohan were sworn in the following year. ${ }^{55}$ Martin claimed that by 1913 practically every senior Fianna officer throughout the country had become a member of the I.R.B. ${ }^{56}$

At the third annual ard-fheis in July 1912, the constitution was amended to assert that the object of the Fianna was to re-establish the independence of Ireland, and that this object was to be achieved through 'the training of the youth of Ireland, mentally and physically ... by teaching scouting and military exercises, Irish history, and the Irish language'. Members promised 'to work for the Independence of Ireland, never to join England's armed forces, and to obey [their] superior officers. ${ }^{57}$

It was no coincidence that 1912 was the year Hobson started a special Fianna circle of the I.R.B., following his election as the Dublin centre of that secret society. This new Fianna circle was known as the John Mitchel Literary and Debating Society, with Colbert as head. The membership included Ó Riain, Martin, Lonergan, Holohan, Seán Heuston, Desmond Ryan and the Mellows brothers, Liam and Barney. ${ }^{58}$

The 1912 annual congress was revolutionary in another way. Resolutions were carried by small majorities to admit girls to the organisation, and to instruct district councils to establish girls' sluaighte. These resolutions generated a great deal of discussion, with emotions running high. Boys who were against the admission of the opposite sex argued that there should be a separate organisation founded for girls. In the end, the resolution to admit girls was carried by only one vote. ${ }^{59}$ Even though she was reputed to not like girls ${ }^{60}$ the countess was the one who managed to carry the proposal to open the Fianna to her own gender. The suffragist newspaper, Irish Citizen, reported that this feminist advance was later flouted by 'the newly-elected committee of the Fianna, which [endeavoured], by delay and obstruction, to thwart the expressed wishes of the congress which elected it'. ${ }^{61}$ Implying that the ard-fheis's decision to open the Fianna to girls was invalid because some troops were not represented at the event, the ard-choisde held a plebiscite among the sluaighte in which a majority (12 to 5) voted in favour of changing the constitution back to its original boys-only condition. Six of the twelve branches that voted against the inclusion of girls in the organisation were based in the Dublin area. Of the five sluaighte that supported female membership, three

54 Fianna handbook, p. 23.

55 Eamon Martin, B.M.H. witness statement, n.d. (N.A.I., B.M.H., WS 591); Patrick Ward, B.M.H. witness statement, 30 Mar. 1955 (ibid., B.M.H., WS 1, 140); Garry Holohan, B.M.H. witness statement, n.d. (ibid., B.M.H., WS 328).

56 Eamon Martin, B.M.H. witness statement, n.d. (ibid., B.M.H., WS 591).

57 Irish Freedom, Sept. 1912. Hobson stated that this amendment was passed in 1913 , but contemporary newspaper reports indicate that the change took place in 1912 (Hobson, 'I.R.B. and Fianna', p. 20).

${ }^{58}$ Hobson, 'I.R.B. and Fianna', p. 21.

59 Irish Freedom, Aug. 1912.

${ }^{60}$ Helena Molony, B.M.H. witness statement, n.d. [prob. 1950] (N.A.I., B.M.H., WS 391).

${ }^{61}$ Irish Citizen, 10 Aug. 1912. 
were listed as being based in Belfast, while the two others had names associated with Ulster. ${ }^{62}$

In fact, a girls' branch of the Fianna had existed in Belfast since 1911, though it had faced 'endless opposition' before it became affiliated with the Belfast district council. ${ }^{63}$ According to the newspaper Bean na hÉireann, it was named in honour of the late Belfast poet, Ethna Carbery. When Markievicz had given the oration at the annual Manchester Martyrs commemoration in November 1911 in Belfast, this girls' sluagh had presented an exhibition of drill that 'received general approbation'. ${ }^{64}$ The establishment of a girls' sluagh may have been a nationalist reaction to the formation in Belfast in 1910 of what was probably the only pre-war Girl Guides' company in Ireland. ${ }^{65}$

By the summer of 1912 Belfast's one and only girls' troop was known as the Betsy Gray sluagh, after a heroine of the 1798 rebellion. It is unclear whether the Ethna Carbery branch had changed its name or had folded and been replaced with a new girls' troop. ${ }^{66}$ In any case, James Connolly's daughters Nora and Ina became leading members. ${ }^{67}$

Ernest Blythe, a Belfast member of the I.R.B. and future Free State finance minister, later contested the evidence provided by the results of the 1912 plebiscite, in which the Betsy Gray sluagh was among the Belfast troops that voted in favour of female membership. He contended that 'the Belfast boys tried to get rid of the girls' branch every year at the organisation's ard-fheis, and [that] it survived only because of the support of the other groups "who had no girls to annoy them". ${ }^{68}$ Although the Belfast girls' sluagh was barred from affiliating to the ard-choisde, representatives, such as the Connolly sisters, continued to attend the annual ardfheis. ${ }^{69}$ Despite calls for a separate girls' organisation to be established nationally, Markievicz did not undertake the task. ${ }^{70}$

${ }^{62}$ Irish Freedom, Sept. 1912. The sluaighte against the inclusion of girls: An Cead Sluagh (1st Dublin Co.), Sluagh Emmet (3rd Dublin Co.), Sluagh Wolfe Tone (5th Dublin Co.), Sluagh Patrick Sarsfield (6th Dublin Co.), Sluagh Fiach Mac Aodha (Baile Breach), Sluagh Finegal (Lusk), Sluagh Lord Edward (Limerick), An Cead Sluagh Corcaighe, Sluagh Leo Cathasaigh (Athlone), Sluagh Wolfe Tone (1st Kerry Co., Listowel), Sluagh Vinegar Hill (Enniscorthy) and Sluagh John Mitchel (Derry). The sluaighte in favour of the inclusion of girls: Sluagh Willie Nelson (Belfast), Sluagh Henry Munroe (Belfast), Sluagh Betsy Gray (Belfast), Sluagh H.J. McCracken and Sluagh Seáin Uí Néill.

${ }^{63}$ Sinéad McCoole, No ordinary women: Irish feminist activists in the revolutionary years, 1900-1923 (Dublin, 2003), p. 26.

${ }^{64}$ Irish Freedom, Dec. 1911.

${ }^{65}$ Fitzpatrick, 'Militarism in Ireland', p. 383. R. A. Voeltz has argued that the social conditions generated by the First World War contributed to the rapid expansion of the Girl Guides' movement in Britain from 1916 onwards ('The antidote to "Khaki Fever"? The expansion of the British Girl Guides during the First World War' in Jn. Contemp. Hist., xxvii (1992), pp 627-38).

${ }^{66}$ Irish Freedom, Sept. 1912.

${ }^{67}$ Nora Connolly O’Brien, B.M.H. witness statement, n.d., (N.A.I., B.M.H., WS 286); Ina Connolly Heron, B.M.H. witness statement, 25 Jan. 1954 (ibid., B.M.H., WS 919); McCoole, No ordinary women, p. 26.

${ }^{68}$ Aodán Mac Póilin, 'Irish language writing in Belfast after 1900' in Nicholas Allen and Aaron Kelly (eds), The cities of Belfast (Dublin, 2003), p. 136.

${ }^{69}$ Nora Connolly O'Brien, James Connolly: portrait of a rebel father (Dublin, 1975), p. 177.

${ }^{70}$ Helena Molony, B.M.H. witness statement, n.d. [prob. 1950] (N.A.I., B.M.H., WS 391). 
The fourth annual ard-fheis, in July 1913, may not have been controversial on the surface, ${ }^{71}$ but behind the scenes, Fianna officers who were also members of the I.R.B. had gained control of the organisation (and were to hold sway until 1923). From 1913 onwards, it became the practice that the night before the ard-fheis, all Fianna officers who were I.R.B. members attended a meeting of the Fianna circle at which 'all matters of policy were decided'. Martin recalled that 'certain resolutions of no great importance were left open for free voting but apart from the discussion arising out of these the rest was all so much eye-wash'. Although these young men - they were hardly boys anymore - found it expedient to retain the countess as president, Martin revealed that 'she really had no voice in shaping policy and was overruled or out voted whenever her ideas ran counter to the decisions of this group' ${ }^{72}$ While Martin believed that Markievicz was oblivious to the takeover by I.R.B. members, her biographer, Jacqueline Van Voris, claimed that the countess 'was aware of it almost at once', and often expressed her disapproval of secret societies. ${ }^{73}$ Markievicz had her own cadre within the Fianna, which was known as 'Madame's boys' or the 'Surrey House clique', in reference to her home on Leinster Road in Rathmines, where they gathered. ${ }^{74}$

In July 1913, the same month that the ard-fheis was held, Hobson suggested to the Dublin Centres Board of the I.R.B. that members should start drilling in preparation for the formation of a military body along the lines of the Ulster Volunteer Force, which had been established in January of that year. Drilling began in the summer of 1913 at 41 Parnell Square in Dublin, the base of the Irish National Foresters, where Ó Riain's father worked as caretaker. Members of the Fianna circle of the I.R.B., including Lonergan, Ó Riain, Colbert and Martin, served as drill instructors. ${ }^{75}$ Lonergan later boasted that he "was the first man in Ireland who taught Patrick Pearse to "form fours". 76

When Hobson helped to form the Irish Volunteers in November 1913, he recruited five senior members of the Fianna to the provisional committee of the new body: Ó Riain, Colbert, Martin, Lonergan and Liam Mellows. These young men visited various halls in the evenings, instructing the officers and directing the course of training. Not surprisingly, most of these officers were I.R.B. members who had received training from these senior Fianna members prior to the formation of the Volunteers. ${ }^{77}$

In addition to providing officers and instructors to the new body, the Fianna contributed numerous rank-and-file Volunteers. The Fianna introduced a new rule in which members who had reached the age of eighteen but had not achieved

${ }^{71}$ Irish Freedom, Aug. 1913.

${ }_{72}$ Eamon Martin, B.M.H. witness statement, n.d. (N.A.I., B.M.H., WS 591).

${ }^{73}$ Van Voris, Constance de Markievicz, pp 89-90.

${ }^{74}$ Seamus Pounch, B.M.H. witness statement, n.d. (N.A.I., B.M.H., WS 267). These boys included Pounch, Patsy O'Connor, Harry Walpole, Jack Shallow, Eddie Murray and Andy Dunne.

${ }^{75}$ Hobson, Ireland, p. 18; idem, 'I.R.B. and Fianna', pp 21-2.

${ }^{76}$ Michael Lonergan, B.M.H. witness statement, 1 Aug. 1948 (N.A.I., B.M.H., WS 140).

77 Eamon Martin, B.M.H. witness statement, n.d. (ibid., B.M.H., WS 591). 
the rank of lieutenant were automatically transferred to the Volunteers. Martin deemed the arrangement a success: 'It gave to the Volunteers [recruits] who were already fully trained and for the Fianna it solved the problem of the young men of eighteen years and over, for whom there were not sufficient officer positions. ${ }^{78}$ For instance, Patrick Ward was instructed to leave the Fianna and join the Volunteers shortly after the establishment of the latter body. ${ }^{79}$

The militant mind-set and military training promoted by the Fianna was as valuable to the Irish Volunteers as it was to the I.R.B. Patrick Pearse, writing in Irish Freedom, was among those who recognised the value of the Fianna: ${ }^{80}$

We believe that Na Fianna Éireann have kept the military spirit alive in Ireland during the past four years, and that if the Fianna had not been founded in 1909, the Volunteers of 1913 would never have arisen. In a sense, then, the Fianna have been the pioneers of the Volunteers; and it is from the ranks of the Fianna that the Volunteers must be recruited.

Pearse's reasoning could be extended to argue that the Easter Rising might not have been possible without the foundation of the Fianna in 1909.

Naturally, Hobson was also a keen advocate of the mutual benefits of the Fianna and the Volunteers. In an address to a conference of the Munster sluaighte in 1915, he 'appealed for a reciprocity between Volunteers and Fianna, and pointed out how the future of the Volunteer movement would depend upon the training and spirit of the boys of to-day'. He also encouraged Volunteer officers to form boy-scouts' troops associated with their companies, pointing out how the scouts could be of value to the adult organisation. ${ }^{81}$ As in the case of the I.R.B., there was an unofficial link between the Fianna and the Irish Volunteers from the inception of the latter organisation. However, although co-operation between the two organisations was naturally close, there was no formal affiliation between the two until after the Easter Rising. ${ }^{82}$

There were also connections between the Fianna and Cumann na mBan, which was formed in April 1914 as the women's counterpart to the Irish Volunteers. In Belfast, the Betsy Gray sluagh became a recruiting ground for the branch of Cumann na mBan founded there by Nora Connolly. ${ }^{83}$ Connolly's influence and Fianna training helped to ensure that the Belfast members were often the best shots in the new women's organisation. ${ }^{84}$ Fianna officer Séamus Pounch trained Cumann na mBan members in Dublin, while Margaret Skinnider, a Cumann na mBan member who participated in the Easter Rising, trained and drilled the Fianna in Glasgow. ${ }^{85}$ Cumann na mBan eventually formed a girl-scouts' organisation, the Cailíní, in $1933 .{ }^{86}$

78 Ibid.

79 Patrick Ward, B.M.H. witness statement, 30 Mar. 1955 (ibid., B.M.H., WS 1,140).

${ }^{80}$ Irish Freedom, Feb. 1914.

${ }^{81}$ Irish Volunteer, 5 June 1915.

${ }^{82}$ Hobson, Ireland, p. 18; idem, 'I.R.B. and Fianna', p. 22.

${ }^{83}$ Nora Connolly O’Brien, B.M.H. witness statement, n.d. (N.A.I., B.M.H., WS 286).

${ }^{84}$ Denis McCullough, B.M.H. witness statement, 11 Dec. 1953 (ibid., B.M.H., WS 915);

Margaret Ward, Unmanageable revolutionaries (London, 1995), p. 104.

${ }^{85}$ Seamus Pounch, B.M.H. witness statement, n.d. (N.A.I., B.M.H., WS 267); Daniel

Branniff, B.M.H. witness statement, n.d. (ibid., B.M.H., WS 222).

${ }^{86}$ Ward, Unmanageable revolutionaries, p. 93. 
The year 1913 saw a further expansion of the Fianna around the country after Liam Mellows was sent on the road between April and November as the Fianna's new full-time organiser and instructor. Although a special fund was set up for his maintenance, his expenses were few because he travelled around the country on his own Irish-built bicycle and stayed with people connected to the I.R.B. ${ }^{87}$ Eamon Martin credited the increasing growth of the Fianna from 1913 onwards as a 'testimony' to Mellows's work in establishing new branches and giving existing troops a boost ${ }^{88}$ For instance, new sluaighte were established in Wexford and Tullamore in 1913. The Tuam and Liverpool branches may have been formed around this time as well.

The momentum continued into 1914. Between January and October of that year, eleven new sluaighte were formed in Gorey, Ballybunion, Cashel, Tipperary, Carrickon-Suir, Mitchelstown, Athy, Sandyford, Clontarf, Chapelizod and Tallaght. ${ }^{89}$ It could be argued, however, that this growth was also connected to the establishment of the Volunteer movement, as many sons of Volunteers joined the Fianna. ${ }^{90}$

By February 1914 the Dublin sluaighte had formed a battalion consisting of two companies, 'A' and ' $\mathrm{B}$ ', ${ }^{91}$ possibly to bring themselves in line with the emerging organisational structure of the Volunteers. The Dublin Battalion again reorganised, expanding into three companies in July $1914 .{ }^{92}$ By the following month, it had over 350 members. ${ }^{93}$ The Limerick branch, in contrast, had decreased from a high of 250 boys down to about 160 by May $1914 .{ }^{94}$

The year 1914 also saw the opening of a Fianna headquarters at 12 D'Olier Street, and the launch of two Fianna publications. ${ }^{95}$ In that year, the ard-choisde finally issued the Fianna handbook in order to instruct and guide members of the Fianna. The first Fianna Christmas annual also appeared in 1914. Nollaig na bhFian, which was edited by Fianna members Patsy O'Connor and Percy Reynolds, was not published by Fianna headquarters but did have official sanction. Buoyed by its financial success, the pair established an unofficial monthly paper entitled Fianna in February 1915. ${ }^{96}$

${ }^{87}$ C. D. Greaves, Liam Mellows and the Irish revolution (London, 1971), pp 48, 53.

${ }^{88}$ Eamon Martin, B.M.H. witness statement, n.d. (N.A.I., B.M.H., WS 591).

${ }^{89}$ B.M.H. Chronology, part I, 1913-21 (U.C.D.A., McCullough Papers, P120/24/13); Irish Volunteer, 7 Feb. 1914.

${ }^{90}$ Robert Holland, A short history of Fianna Éireann, 14 Aug. 1949, p. 19 (N.L.I., MS $35,455 / 3 / 12 \mathrm{~A})$.

${ }_{91}$ Irish Volunteer, 14 Feb. 1914.

92 After the July 1914 reorganisation of the Dublin Battalion, a company consisted of three officers (one captain and two lieutenants), four leaders, eight corporals and sixty-four scouts. A company was divided into four sections: a section consisted of one leader, two corporals and sixteen scouts. Two sections formed a half-company under a lieutenant. A military council supervised training and issued orders (Irish Volunteer, 25 July 1914).

${ }^{93}$ Ibid., 22 Aug. 1914.

${ }^{94}$ Ibid., 30 May 1914.

95 Irish Freedom, June 1914.

${ }^{96}$ Irish Volunteer, 21 Nov., 9 Jan. 1915. For a discussion of these three Fianna publications, see Marnie Hay, 'This treasured island: Irish nationalist propaganda aimed at children and youth, 1910-16' in Celia Keenan and Mary Shine Thompson (eds), Treasure islands in children's literature (Dublin, 2006), pp 33-42. 
In June 1914 Hobson's role within the I.R.B. diminished after he defied I.R.B. orders and supported, for strategic reasons, the acceptance of Irish Parliamentary Party leader John Redmond's nominees to the provisional committee of the Irish Volunteers. Redmond, alarmed by the growing popularity of the Volunteers, had threatened to split the movement if twenty-five of his nominees were not co-opted to this governing committee. In Hobson's view, the Volunteer movement was not yet strong enough to withstand a split. Convinced that a strong minority group could secretly control the committee, Hobson not only voted in favour of the co-option of the nominees, but influenced others to vote likewise, ensuring the acceptance of the nominees. Although his actions succeeded in postponing a split in the Volunteer movement until after the outbreak of the First World War, they earned him the wrath of Tom Clarke and Seán MacDermott, the most powerful members of the I.R.B. executive.

Hobson's falling-out with Clarke and MacDermott does not appear to have affected his role within the Fianna nor diminished the position of the Fianna officers within the I.R.B., with the possible exception of Ó Riain, a close friend of Hobson's. In October 1914 Hobson was re-elected vice-president at the fifth annual Fianna ard-fheis. ${ }^{97}$ According to Garry Holohan, 'the Fianna officers with, I should think, the exception of Con Colbert, still had implicit faith in Bulmer Hobson, while at the same time we enjoyed the full confidence and friendship of Tom Clarke and Sean McDermott' ${ }^{98}$ Martin suggested that Hobson's role in the Fianna was not affected by his bitter conflict with Clarke and MacDermott because his 'counsel and guidance' had 'so impressed and influenced the young men of the [Fianna], all of whom held him in high esteem'. Martin - who voted against the acceptance of Redmond's nominees - and Holohan ultimately agreed that Hobson's actions were justified. In Holohan's opinion, Hobson, Clarke and MacDermott 'were all equally sincere in their efforts to advance the movement as they thought best'. ${ }^{99}$

Shortly after the co-option of Redmond's nominees to the Volunteer committee, the Fianna had the opportunity to put its skills to work in a real-life military manoeuvre when it assisted in the landing of arms and ammunition at Howth on 26 July 1914. About 200 members of the Fianna participated in the event. Hobson, who organised the landing, instructed them to bring their trek-cart loaded with wooden batons to Howth and to distribute these batons to the Volunteers for protection in case of police interference. Six Fianna members were responsible for signalling - both in Morse code and semaphore - to the Asgard from the Hill of Howth. ${ }^{100}$ When the yacht docked at the pier, the Fianna was ordered to fill the trek-cart with 2,000 rounds of ammunition and bring it back to Dublin. Hobson felt that the Fianna was 'the only body with sufficient discipline to be entrusted with ammunition' at that time. ${ }^{101}$ When a second shipment of arms arrived in Kilcoole on the night of 1 August 1914, Holohan and Ward were among the Fianna members who helped to land the cargo and transport it to Dublin. ${ }^{102}$

${ }^{97}$ Irish Volunteer, 17 Oct. 1914.

${ }^{98}$ Garry Holohan, B.M.H. witness statement, n.d. (N.A.I., B.M.H., WS 328).

${ }_{99}$ Eamon Martin, B.M.H. witness statement, n.d. (ibid., B.M.H., WS 591); Garry Holohan, B.M.H. witness statement, n.d. (ibid., B.M.H., WS 328).

${ }^{100}$ Robert Holland, B.M.H. witness statement, 18 July 1949 (ibid., B.M.H., WS 280).

${ }^{101}$ Hobson, 'I.R.B. and Fianna', p. 22.

${ }^{102}$ Garry Holohan, B.M.H. witness statement, n.d. (N.A.I., B.M.H., WS 328). 
Hobson excluded Markievicz and the female members of the Fianna from the Howth gun-running, provoking their anger and disappointment. Ina Connolly recalled: 'It really looked as if we were not trusted ... Had I been a boy I would not have been overlooked.' ${ }^{103}$ However, she and her sister Nora, who were camping with the countess and some Fianna boys in the Wicklow hills that weekend, were later asked to smuggle guns to Belfast, a risky task that they completed successfully. ${ }^{104}$

The split in the Irish Volunteers in September 1914 had an impact on membership numbers in the Fianna, both positively and negatively. The split occurred after Redmond, without consultation, urged the Volunteers to fight in the First World War. While a majority followed Redmond under the new name, National Volunteers, and joined the British Army, a minority adhered to the force's original aims and name. After the split, Redmond's supporters in the Irish Parliamentary Party denounced the Irish Volunteers and the Fianna, particularly for their stance against recruitment into the British military. Ó Riain commented: ${ }^{105}$

Not being satisfied with their efforts to disrupt the adult Volunteer organisation, many of the party politicians who pollute the public life of our country showed unusual zeal in attributing Sinn Féin tendencies to the Fianna. A self-governing boys' organisation is inconceivable to the mentality of the machine politician.

For instance, the mayor of Kilkenny allegedly urged 'boys not to sign the Fianna declaration' and to secede from the organisation. In Belfast, 'the same sort of tactics' were pursued by 'an ignorant section' of the A.O.H. ${ }^{106}$

Ó Riain noted that such publicity attracted 'hundreds of recruits' in places like Dublin, where the Fianna organisation was strong. ${ }^{107}$ By November 1914 the Dublin Battalion boasted 500 members. ${ }^{108}$ However, while Waterford 'weathered the storm that ... wrecked more than one of our country sluaighte', other places were not so resilient. ${ }^{109}$ For example, in June 1915 only three Belfast troops were described as 'hard at work', ${ }^{110}$ and by November 1915 membership in the Limerick sluagh was down to sixty boys. ${ }^{111}$

Despite this dip in numbers, Ó Riain reported in April 1915 that the first five years of the Fianna's existence had placed the organisation on a sound basis. But there was still much more work to be done because 'only a small fraction of the boys of Ireland' had pledged themselves to the Fianna. Ó Riain warned members that they could not 'afford to go plodding along slowly' as they had previously. Alluding to the possibility that Britain's weakness during the First World War

${ }^{103}$ Ina Connolly Heron, B.M.H. witness statement, 25 Jan. 1954 (ibid., B.M.H., WS 919).

${ }^{104}$ Ward, Unmanageable revolutionaries, pp 105-6.

${ }^{105}$ Irish Volunteer, 13 Feb. 1915.

${ }^{106}$ Ibid., 14 Nov. 1914.

${ }^{107}$ Ibid.

${ }^{108}$ Ibid., 28 Nov. 1914.

${ }^{109}$ Ibid., 13 Feb. 1915.

${ }^{110}$ Ibid., 12 June 1915.

${ }^{111}$ Ibid., 13 Nov. 1915. 
might be Ireland's opportunity, he predicted that 'great changes' in the country's national life were ahead, and advised the Fianna to 'be organised and strong' in order to prevent the movement from 'being submerged by coming crises'. ${ }^{112}$

To prepare for these coming crises, the Dublin district council expanded its battalion into nine companies. ${ }^{113}$ In addition, the Fianna reorganised its governing body at the sixth annual ard-fheis in July $1915 .{ }^{114}$ Captain Eamon Martin proposed resolutions that provoked a lengthy discussion that had probably been rehearsed at an I.R.B. meeting beforehand. He suggested that the presidency of the Fianna should be abolished and replaced with a Fianna chief who would have military command of the entire organisation, and that the ard-choisde should be replaced by a 'competent' headquarters' staff that would help the Fianna chief run the organisation. Martin asserted 'that the anomaly of having a president instead of a military chief at the head of their organisation was ludicrous' in a movement that over the years had become 'essentially a military one'. He added that over the past six months, the general secretary, rather than the ard-choisde, had been doing most of the work at its D'Olier Street headquarters. Due to the growth of the Fianna, the workload was now too great to be done efficiently by one or two boys.

Hobson opposed the resolutions, pointing out that if they were passed, the ard-fheis would be handing over 'the government of the Fianna to a half-dozen Fianna officers'. He argued that 'there was a civil side in the Fianna which was of even greater importance than the military one'. Hobson may have been 'scripted' at the I.R.B. meeting prior to the ard-fheis to play the part of devil's advocate. Alternatively, he may have feared that the I.R.B. would draw the Fianna into a premature insurrection. Although Clarke and MacDermott kept Hobson - whom they no longer trusted - in the dark about their precise plans for a rising, he had been informed of the decision to stage an insurrection before the end of the war. ${ }^{115}$

Through discussion, the proposed changes were eventually crafted into a compromise. The ard-fheis decided to retain Markievicz's position as president and elect an ard-choisde of twelve members, which was instructed to appoint an ard fhéinne (Fianna chief) and headquarters' staff at its first meeting. ${ }^{116}$ The subsequent appointments of Ó Riain as ard fhéinne and Hobson as chief of staff hint at the deterioration in relations between Markievicz and Hobson.

When the Fianna was established in 1909, Hobson and Markievicz were close nationalist associates. He had been her first mentor within the Sinn Féin movement. In late 1909, along with Helena Molony, the pair even ran a short-lived commune at Belcamp Park in Raheny, where Fianna boys held weekend camps and engaged in shooting practise. Over time, however, their relationship suffered

112 Ibid., 17 Apr. 1915.

${ }^{113}$ Joseph Reynolds, B.M.H. witness statement, n.d. (N.A.I., B.M.H., WS 191); Eamon Martin, B.M.H. witness statement, n.d. (ibid., B.M.H., WS 591); Irish Volunteer, 29 May 1915.

${ }^{114}$ Eamon Martin, B.M.H. witness statement, n.d. (N.A.I., B.M.H., WS 591).

${ }^{115}$ Denis McCullough, B.M.H. witness statement, 13 Apr. 1948 (ibid., B.M.H., WS 111); Denis McCullough to Pádraig Ó Maidín, n.d. (U.C.D.A., McCullough Papers, P 120/23/20).

${ }^{116}$ Fianna, Aug. 1915. In addition to the president, Markievicz, the following were elected to the ard-choisde: Bulmer Hobson, Pádraig Ó Riain, Eamon Martin, J. A. Dalton, Con Colbert, Seán Heuston, Leo Henderson, Pádraig O’Daly, Garry Holohan, Barney Mellows, Percy Reynolds and Niall MacNeill. 
due to political differences. Markievicz and Molony resented the control that the I.R.B. had over their nationalist men friends. They were incensed in July 1911 when these young men, on I.R.B. orders, journeyed to Wolfe Tone's grave in Bodenstown to commemorate the anniversary of his death instead of staying in Dublin to participate in street protests against the royal visit. ${ }^{117}$ They assumed that they had convinced Hobson to join them on the streets, and so felt doubly betrayed when he, too, accompanied the Bodenstown crowd. Markievicz later accused her one-time mentor of being 'one of those who preferred the limelight and laurels to be won by a fierce speech at a rebel's graveside to the possibility of getting a hammering from the police or being arrested'. ${ }^{118}$ Hobson's opposition to active I.R.B. support for the workers during the 1913 Lock-out ${ }^{119}$ and his acceptance of Redmond's nominees to the provisional committee of the Irish Volunteers also had an adverse effect on his relationship with the countess. Thus, the seemingly incongruous appointments of Ó Riain, a natural organiser, to a role that was 'really no more than an honour', and father figure Hobson to a managerial position, were designed to appease Markievicz. ${ }^{120}$ Martin explained:

[w]hile Madame [Markievicz] might feel hurt because she herself was not given the title of ard fhéinne she would tolerate it going to Pádraig, but by this time she would never have stood for it going to Bulmer. Therefore, these two positions were filled in this way because it was still considered expedient that Madame should not be too openly antagonised.

In fact, Hobson became only nominal chief of staff. Instead, Ó Riain directed and co-ordinated the work of the various departments. In addition, Markievicz's re-election to the position of president had been arranged behind the scenes in order to ensure that she was not eligible for appointment to headquarters' staff. ${ }^{121}$

\section{VI}

Under its new organisational structure, the Fianna continued to extend and intensify its military-training programme. In the period from the summer of 1915 to the spring of 1916, many members felt that the Fianna, along with its republican colleagues in the I.R.B. and the Irish Volunteers, was 'moving rapidly towards a climax', which, as it turned out, was the Easter Rising.

Martin was one of the first Fianna members to get any 'definite information' about the planned insurrection. He heard about it on the Sunday before Easter 1916. ${ }^{122}$ That same night, Hobson gave an impromptu speech at a concert organised

\footnotetext{
${ }^{117}$ Helena Molony, B.M.H. witness statement, n.d. [prob. 1950] (N.A.I., B.M.H., WS 391); Marreco, Rebel countess, p. 142.

${ }^{118}$ Quoted in Marreco, Rebel countess, p. 142.

${ }^{119}$ Members of the Fianna joined Markievicz in supporting the workers during the Dublin Lock-out of 1913. One member, Patsy O'Connor, was administering first aid to an injured worker during a police baton charge when he, too, was attacked; he sustained a head injury that eventually resulted in his death (Irish Volunteer, 26 June 1915).

${ }^{120}$ The other appointments to headquarters' staff were: adjutant - Percy Reynolds; director of training - Seán Heuston; director of organisation and recruiting - Eamon Martin; director of equipment - Leo Henderson; director of finance - Barney Mellows (Irish Volunteer, 24 July 1915).

${ }^{121}$ Eamon Martin, B.M.H. witness statement, n.d. (N.A.I., B.M.H., WS 591).

${ }^{122}$ Ibid.
} 
by Cumann na mBan. In 'guarded language', he 'warned' the Volunteers in the audience 'of the extreme danger of being drawn into precipitate action', which he believed 'could only have the effect of bringing the Volunteer movement to an end'. He added that 'no man had a right to risk the fortunes of the country in order to create for himself a niche in history'. ${ }^{123}$ Hobson was only in favour of insurrection if Germany provided enough assistance to guarantee military success or if Britain attempted to suppress the Volunteers. Instead, he favoured a campaign of guerrilla warfare.

Martin did not hear about Hobson's guerrilla-warfare plan until after the Rising. Even though he viewed this plan as 'sound and practicable', Martin maintained that he would still have supported an insurrection, explaining that Pearse's doctrine of the blood sacrifice 'had a greater appeal for those who had become tired of waiting for favourable opportunities'. Martin, like others, felt it would be 'shameful and disastrous' if the First World War ended before any attempt was made to take advantage of Britain's difficulty. Thus, 'even a glorious failure would be better than no attempt at all'. ${ }^{124}$ As Hobson did not share this enthusiasm for a blood sacrifice and the triumph of failure, the Easter Rising proved to be the parting of the ways between him and his young associates in the Fianna.

In contrast to Hobson, many former and current members of the Fianna did participate in the Rising, as commanders, fighters, dispatch carriers and scouts. Seven were killed in action. ${ }^{125}$ Among the fifteen leaders executed for their part in the Rising were two young men connected with the Fianna: Seán Heuston director of training at Fianna headquarters and vice-commandant of the Dublin Battalion - took charge of the Mendicity Institute at Usher's Island, while Colbert was second-in-command at Marrowbone Lane Distillery, and took command at the surrender. Heuston and Colbert were executed on 8 May 1916. ${ }^{126}$ Markievicz, who had been one of the commanders at Stephen's Green and the College of Surgeons, was spared the same fate by her gender.

Some members of the Fianna, including Volunteer leader Eoin MacNeill's son Niall, were court-martialled by the organisation for not taking part in the Rising. Markievicz, Barney Mellows and a third (unnamed) Fianna officer exonerated Niall MacNeill on the grounds that he had been under his father's influence. MacNeill saw such courts martial as a 'face-saving' device to keep certain useful people in the Fianna movement. ${ }^{127}$

The Fianna reorganised shortly after the Easter Rising, and attracted an all-time high of over 30,000 members by June $1917 .{ }^{128}$ In 1924, following the Civil War, the organisation revamped itself yet again: it returned to the original sluagh system and issued a new handbook. The influence of the I.R.B. having faded away, the

${ }^{123}$ Hobson, Ireland, pp 74-5.

${ }^{124}$ Eamon Martin, B.M.H. witness statement, n.d. (N.A.I., B.M.H., WS 591).

${ }^{125}$ The following Fianna members were killed in action during Easter Week: Brendan Donelan, 24 Apr. 1916; Seán Healy, 24 Apr. 1916; James Fox, 25 Apr. 1916; James Kelly, 25 Apr. 1916; Gerald Keogh, 27 Apr. 1916; Seán Howard, 27 Apr. 1916; Frederick Ryan, 27 Apr. 1916. Donelan is listed as being from Galway, while the others were based in Dublin ('Fianna roll of honour' in Holland, A short history, p. 25 (N.L.I., MS 35,455/3/12A)).

${ }^{126}$ Joseph Reynolds, B.M.H. witness statement, n.d. (N.A.I., B.M.H., WS 191).

${ }^{127}$ Col. Niall MacNeill, B.M.H. witness statement, 6-7 Jan. 1948 (ibid., B.M.H., WS 69).

${ }^{128}$ Pádraig Mac Fhloinn, 'The history and tradition of Fianna Éireann' in Fianna Éireann handbook (Dublin, 1988), p. 14. 
countess was able to assert control until her death in $1927 .{ }^{129}$ The organisation tried to emphasise its educational, rather than military, value in a newly independent Irish Free State, where the Baden-Powell Boy Scouts continued to attract higher membership figures, ${ }^{130}$ and in Northern Ireland, where Fianna sluaighte, despite having been outlawed in 1923, remained in existence. ${ }^{131}$

The active role of the Fianna in the Easter Rising, and later in the War of Independence and on the anti-Treaty side during the Civil War, was (and still is) a source of great pride for the organisation. Various commemoration publications featured reprints of articles by Markievicz, Pearse, James Connolly and Roger Casement, and photographs of Fianna members who were executed or killed in action. Not surprisingly, Hobson's name was conspicuous by its absence. Even the 1959 souvenir programme of the fiftieth anniversary of the founding of the Fianna made no mention of his contribution to the organisation in the period 1909-16. ${ }^{132}$ Although individual members of the Fianna, such as Martin and Holohan, thought that Hobson had been unjustly accused of cowardice and treason as a result of his opposition to the Rising ${ }^{133}$ the organisation as a whole appears to have found it expedient - at least for a while - to airbrush him out of the picture after 1916. The 1988 Fianna Éireann handbook acknowledged Hobson as one of the organisation's two founders, ${ }^{134}$ but placed greater emphasis on the contribution of Markievicz, who not only was involved over a longer period of time but also served as a more fitting role model in view of the modern-day Fianna's commitment to republicanism and socialism. ${ }^{135}$

\section{VII}

A degree of controversy surrounds the foundation and control of the Fianna in the period 1909-16. Over three decades later, Helena Molony expressed concern that 'a certain section' were still trying to prove that the countess was 'only a tool' used by Hobson - possibly even the I.R.B. - to start the nationalist youth organisation. Molony added: ${ }^{136}$

I would like it to be understood that she was eighty per cent responsible for it. I am not saying that she did not get valuable help. In fact, she could not have succeeded if she had not got help; but the driving work of carrying it on was hers.

Witness statements to the Bureau of Military History from former members of the Fianna acknowledge the importance of Markievicz's contribution, but indicate

${ }^{129}$ Ibid., pp 13, 18.

${ }^{130}$ In 1926 the (unnamed) editor of Fianna expressed concern that there were 36,000 members of the Baden-Powell Boy Scouts in Ireland. Four years earlier, the Fianna membership stood at 26,000 (Fianna, June 1926, June 1922).

${ }^{131}$ Mac Fhloinn, 'History and tradition', p. 18.

${ }^{132}$ See Fianna Éireann Dublin Brigade, Easter Week 1916-1922 commemoration Aeridheacht souvenir programme, 23 April 1922 (Dublin, 1922); Cathal O'Shannon (ed.), Souvenir of the golden jubilee of Fianna Eireann, Aug. 16, 1909-Aug. 16, 1959 (Dublin, 1959).

${ }^{133}$ Eamon Martin, B.M.H. witness statement, n.d. (N.A.I., B.M.H., WS 591); Garry Holohan, B.M.H. witness statement, n.d. (ibid., B.M.H., WS 328).

${ }^{134}$ Fianna Éireann handbook, pp 9, 134.

${ }^{135}$ Ibid., p. 5 .

${ }^{136}$ Helena Molony, B.M.H. witness statement, n.d. [prob. 1950] (N.A.I., B.M.H., WS 391). 
that real control within the organisation lay with the boys who had been recruited into the I.R.B. The following observation from Martin is typical of the witness statements: ${ }^{137}$

While it is true she was 'used' it is nevertheless true I believe that without her it is doubtful if Bulmer Hobson or anyone else would have embarked upon the project. I believe it needed Madame's enthusiasm, her tremendous energy and above all the abiding faith of such a noble character to have brought the dream to fruition.

In light of Markievicz's antipathy towards Hobson and the I.R.B., it is not surprising that Molony was concerned that 'a certain section' was trying to shift the credit for the Fianna toward Hobson and the I.R.B., and away from her friend. ${ }^{138}$

Markievicz's energy, enthusiasm and money were essential to the establishment of Na Fianna Éireann. In addition to serving as a flamboyant focal point for the organisation, she was able to provide instruction in the use of firearms and bases for shooting practise and camping. Her gender and social position were also reassuring to the parents of younger boys. Hobson brought to the Fianna his considerable organisational and propagandist experience, the template of his previous Belfast boys' group, and his connections to the I.R.B. and later the Irish Volunteers. The efforts of Markievicz and Hobson would have come to nothing, however, if it had not been for the boys and girls themselves. The eagerness, activity, skill and commitment of Ó Riain, Colbert, Martin, the Mellows brothers, Heuston, Holohan, the Connolly sisters and others ensured that the Fianna made an important contribution, both military and educational, to the struggle for Irish independence both before and after Easter 1916. ${ }^{139}$

Marnie Hay School of History and Archives, University College Dublin

${ }^{137}$ Eamon Martin, B.M.H. witness statement, n.d. (ibid., B.M.H., WS 591).

${ }^{138}$ For instance, Tom Clarke's biographer, L. N. Le Roux, claims that the Fianna was instigated by the I.R.B. Supreme Council (Tom Clarke and the Irish freedom movement (Dublin, 1936), p. 102).

${ }^{139}$ Previous versions of this article were delivered to the U.C.D. Open Postgraduate History Seminar in January 2004, the T.C.D. Contemporary Irish History Seminar in April 2004, the Women's History Association of Ireland annual conference in Dublin in November 2004, and the Canadian Association for Irish Studies annual conference in Maynooth in June 2005. I would like to thank audience members for their questions and observations. I am also grateful to Professor Michael Laffan and Dr Charles Ivar McGrath for their comments on earlier drafts of this article. 